\title{
Construction, Characterization and Measurement of Fe-C and Pd-C HTFPs at CEM
}

\author{
M. J. Martín ${ }^{1}$ (D) J. M. Mantilla ${ }^{1} \cdot$ C. Garcia-Izquierdo ${ }^{1} \cdot$ D. del Campo ${ }^{1}$
}

Received: 30 November 2021 / Accepted: 17 January 2022 / Published online: 7 February 2022

(c) The Author(s) 2022

\begin{abstract}
The current state of the art for temperature realization and dissemination above $1300 \mathrm{~K}$ is through the MeP-K-19 [1]. A limited set of high-temperature fixed points (HTFPs), an essential component of the MeP-K-19, has their temperature determined (Co-C $(1597 \mathrm{~K}), \mathrm{Pt}-\mathrm{C}(1011 \mathrm{~K})$ and Re-C $(2747 \mathrm{~K}))$. It is really a need to increase the HTFPs available for realization and dissemination of the high-temperature MeP-K. Fe-C (1426 K) and Pd-C (1765 K) has been less investigated, their thermodynamic temperature hasn't been definitively determined, and they have been considered good candidates for their inclusion in the MeP-K in the EMPIR project "Real-K" [2]. This paper describes the construction, characterization, and measurement of HTFPs of Fe-C and $\mathrm{Pd}-\mathrm{C}$ at Centro Español de Metrología as part of its contribution to the EMPIR project "Real-K". Cells made have hybrid-type crucibles and they have been filled applying the piston method. A series of 6 HTFPs has been constructed: $3 \mathrm{Fe}-\mathrm{C}$ and $3 \mathrm{Pd}-\mathrm{C}$. Points of inflection of the melting plateaux are repeatable after several initial measurement cycles. Their corresponding International Temperature Scale (ITS-90) temperatures $\left(t_{90}\right)$, referenced to a $\mathrm{Cu}$ fixed point, and thermodynamic temperatures $(t)$, by means of the spectral responsivity calibration, have been calculated. Additionally, the influence of the furnace in the temperature assigned to the cells has been determined for different furnaces types (one zone and three zone) and different temperature profiles.
\end{abstract}

Keywords $\mathrm{Fe}-\mathrm{C} \cdot$ Furnace effect $\cdot$ High temperature fixed points $\cdot \mathrm{Pd}-\mathrm{C}$

M. J. Martín

mjmartinh@cem.es

1 Centro Español de Metrología, Tres Cantos, Spain 


\section{Introduction}

ITS-90 realization and temperature dissemination above the silver point $(\sim 1300 \mathrm{~K})$ is in a process of coexistence with the indirect radiometry approach described in the MeP-K-19, using high-temperature fixed points (HTFPs) with assigned thermodynamic temperatures. This indirect radiometry approach can provide better uncertainties (mainly at high temperatures) and can be applied to establish a direct link to the redefined kelvin, using HTFPs of known temperatures.

For this to be achieved, it is necessary to develop a number of HTFPs to cover the whole temperature range above the freezing temperature of copper, the current highest fixed point of the ITS-90. These new fixed points should complement the existing and well known HTFPs Co-C (1597 K), Pt-C (2011 K) and Re-C (2747 K), filling the gaps and extending the temperature range to $3020 \mathrm{~K}$. This is one of the tasks of the joint EMPIR research project Real-K. Centro Español de Metrología (CEM) takes part in this project and more specifically it is in charge of the construction of $\mathrm{Fe}-\mathrm{C}(1426 \mathrm{~K})$ and Pd-C (1765 K) HTFPs.

The following sections will describe the construction process of the cells, the plateaus measured, the $t_{90}$ and $t$ values assigned to the points of inflection (POI) of the cells and an estimation of the uncertainty, including the influence of the furnace.

\section{Method}

\subsection{Construction of the Cells}

The design of CEM cells was described in [3]. Table 1 summarizes their main dimensional parameters. Figure 1 shows a scheme of how the cells are filled at the moment metal-carbon powder mixture has already melted. The part of the alloy that exceeds the capacity of the ingot enters the central evacuation hole of the piston. It can be easily removed from the crucible and serves as sample for the analysis of the impurities present on the alloy.

Eutectic HTFPs filling process, based in the piston method developed by LNECNAM [4, 5], was performed using an Isotech 465 three-zone furnace, shown

Table 1 Dimensional parameters of the cells

\begin{tabular}{ll}
\hline Parameter & Value \\
\hline Outer diameter & $24 \mathrm{~mm}$ \\
Total length with cap & $45 \mathrm{~mm}$ \\
Radiating cavity diameter & $3 \mathrm{~mm}$ \\
BB cavity depth & $35 \mathrm{~mm}$ \\
Volume for the alloy & $4.35 \mathrm{~cm}^{3}$ \\
Inner graphite tube thickness & $1 \mathrm{~mm}$ \\
BB thickness & $2 \mathrm{~mm}$ \\
Crucible thickness & $3 \mathrm{~mm}$ \\
\hline
\end{tabular}




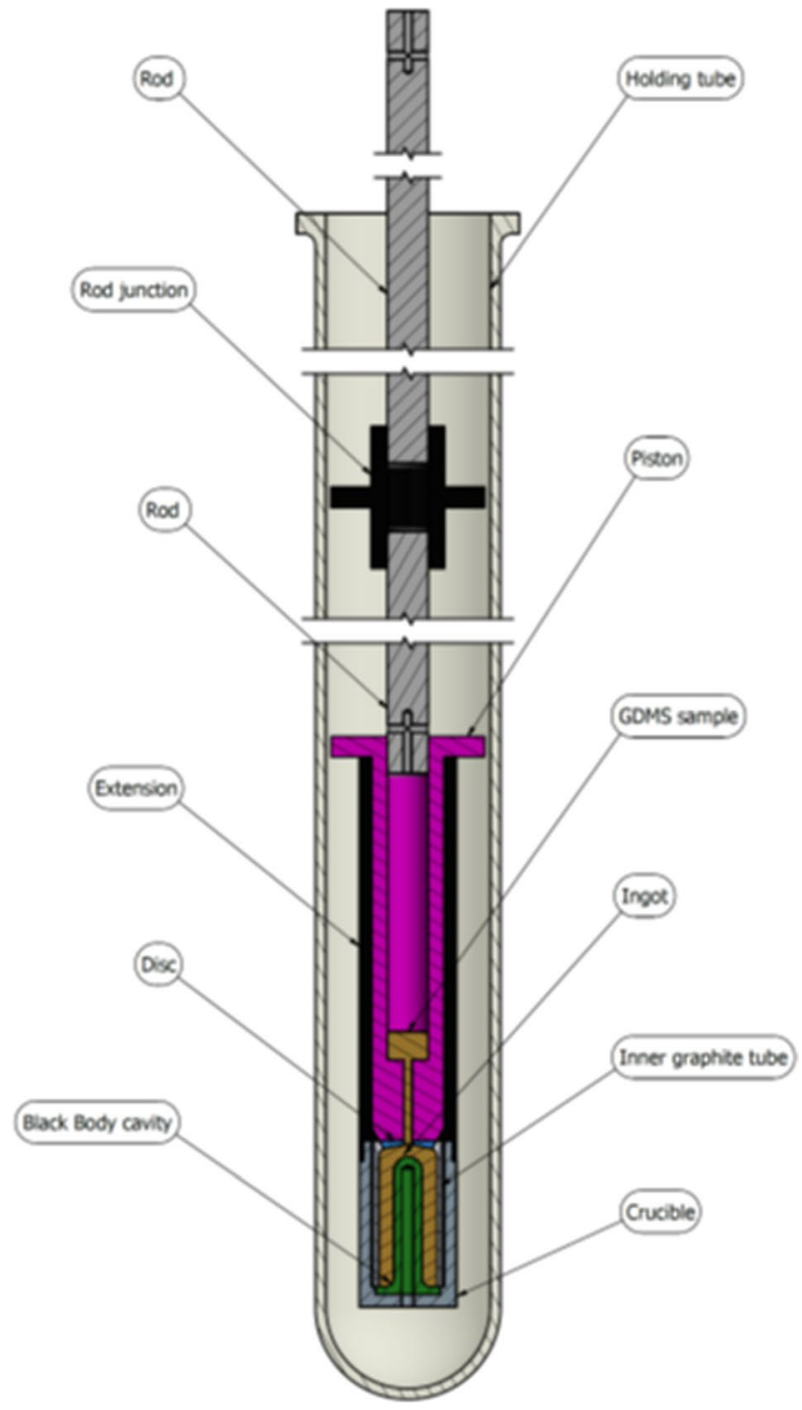

Fig. 1 CEM HTFP filling assembly scheme

in Fig. 2, for Fe-C cells and a non-commercial three-zone furnace with $\mathrm{MoSi}_{2}$ heaters for $\mathrm{Pd}-\mathrm{C}$ cells. Holding tubes used to introduce filling assemblies inside the furnaces have hermetic flanges and a tube that was connected to a circuit that can alternatively produce vacuum with a pump or introduce Ar gas in order to evacuate air from the tube. Filling procedure of the cells was carried out as in [3]. Figure 3 shows the resulting HTFP cells after the filling process. 
Fig. 2 Eutectic HTFPs filling process
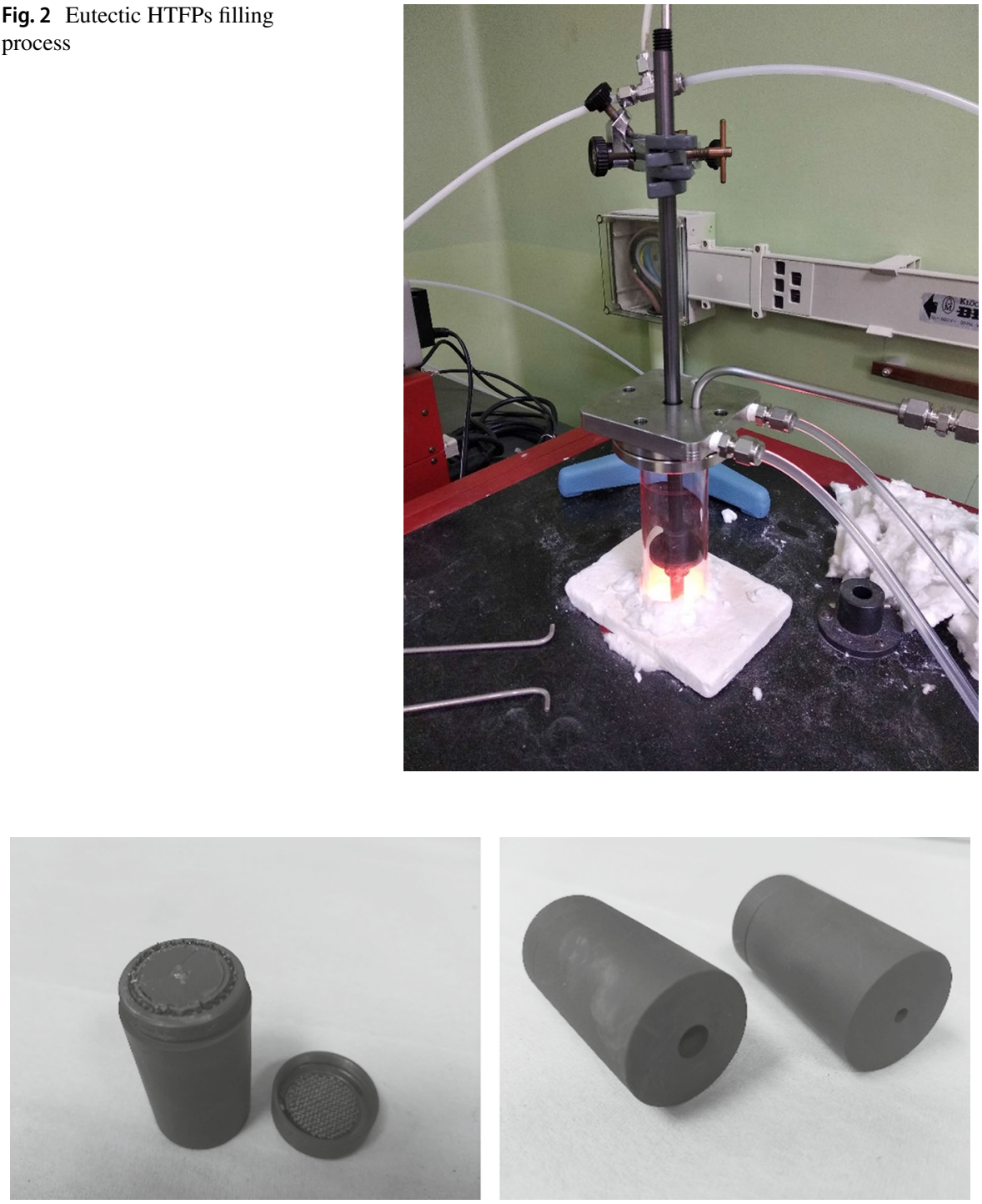

Fig. 3 CEM cells picture

All the parts used for the construction of each cell, after its assembly in the tube, were previously baked in vacuum up to $1000{ }^{\circ} \mathrm{C}$ and in $\mathrm{Ar}$ at approximately $100{ }^{\circ} \mathrm{C}$ above their corresponding melting temperature.

A series of 6 HTFPs were constructed: $2 \mathrm{Fe}-\mathrm{C}$ with blackbody diameter aperture of $3 \mathrm{~mm}, 1 \mathrm{Fe}-\mathrm{C}$ with blackbody diameter aperture of $6 \mathrm{~mm}^{1}$ and $3 \mathrm{Pd}-\mathrm{C}$

\footnotetext{
1 This cell, with larger aperture diameter, has been constructed for dissemination activities included in the Real-K project.
} 
with blackbody diameter aperture of $3 \mathrm{~mm}$. Graphite crucibles, with a purity better than 5 ppm, were supplied by SGL Carbon. Pd powder is $99.99 \%$ pure (Acros Organic), Fe powder $99.99 \%$ pure (Sigma Aldrich) and graphite powder 99.9999\% pure (Alpha Aesar).

$\mathrm{Fe}-\mathrm{C}$ and $\mathrm{Pd}-\mathrm{C}$ cells were filled in a single step with hypoeutectic metal-carbon mixtures $1 \%$ below the carbon composition of the corresponding eutectic fixed point listed in [6], $4.2 \%$ and $2.7 \%$, respectively. Fill level of the cells was calculated from the difference in mass of the crucible before and after a filling process. Cell's volume capacity was converted into mass capacity from $\mathrm{Pd}, \mathrm{Fe}$ and $\mathrm{C}$ densities published by the Royal Society of Chemistry and the weight percent of each added to the mixtures.

Although the piston was fully depressed after their first filling processes, the first two cells constructed (1PdC1 and $1 \mathrm{PdC} 2)$ were suspected to be underfilled according to calculations mentioned on the previous paragraph. Therefore, it was performed a second filling cycle with the aim of improving their robustness and the plateau shape by eliminating the calculated voids of $9 \%$ in CEM $1 \mathrm{PdC} 1$ and $14 \%$ in $\mathrm{CEM} 1 \mathrm{PdC} 2$. Both $1 \mathrm{PdC} 1$ and $1 \mathrm{PdC} 2$ were considered to have reached their maximum capacities in this second step with an ingot mass of $44.1 \mathrm{~g}$ and $44.4 \mathrm{~g}$, respectively. A third $\mathrm{Pd}-\mathrm{C}$ cell (1Pd-C3) has been filled in a single step, after designing a new graphite extension part with higher capacity. Theoretical mass capacity of the cells was never achieved, this was attributed to a difference between the hypoeutectic alloy density and the calculation method applied. Mass differences between cells of the same kind were attributed to voids present inside the ingots.

Samples of $\mathrm{Fe}$ and $\mathrm{Pd}$ powders along with $\mathrm{Fe}-\mathrm{C}$ and $\mathrm{Pd}-\mathrm{C}$ samples, obtained during the filling process of the corresponding cells, were sent to National Research Council of Canada (NRC) for its quantitative Glow Discharge Mass Spectrometric analysis of impurities. Test method used for the analysis of this particular samples was not validated at the time it was performed and, consequently, no uncertainties were included in the final report. Most of the values reported on the samples were compatible with the nominal purity values provided by the metal and graphite suppliers with the exception of the $450 \mathrm{ppm}$ of oxygen detected on the Fe-C sample and the $210 \mathrm{ppm}$ of $\mathrm{Ru}$ reported on the $\mathrm{Pd}-\mathrm{C}$ cell.

Acording to [7], presence of iron oxide on $\mathrm{Fe}-\mathrm{C}$ cells does not have a significant influence on the transition temperature of the eutectic point.

$\mathrm{Ru}$ reported on $\mathrm{Pd}-\mathrm{C}$ sample analysis represents twice supplier's stated powder purity $(100 \mathrm{ppm})$ and it is also the impurity with the highest concentration on the powder sample (56 ppm).

The influence of the impurities on cell's POI of its melting curve will be revealed from the results of the comparison of cells made by CEM with other cells made by other Real-K project partners.

Table 2 summarizes all the HTFP made with their corresponding parameters. 


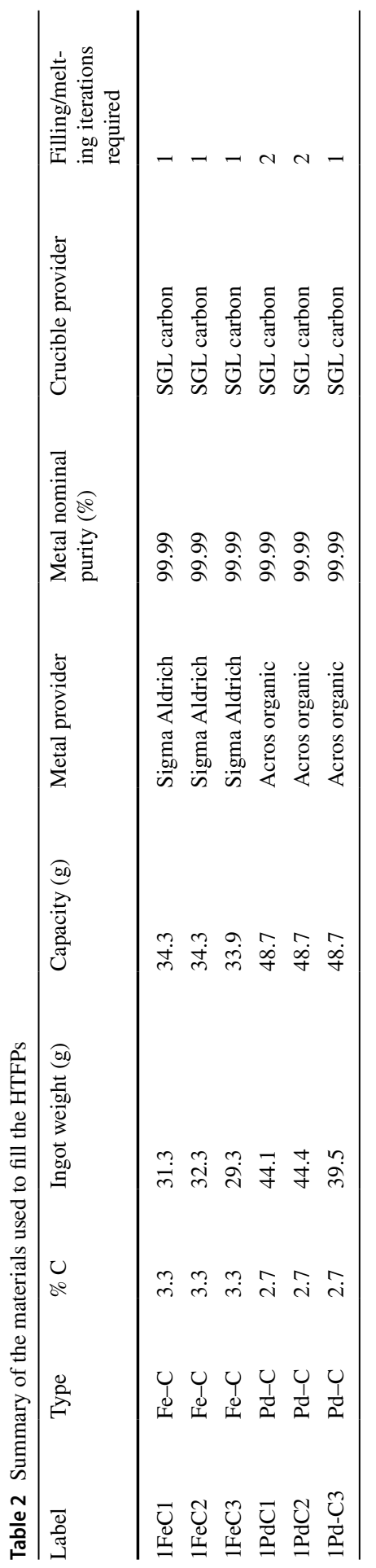




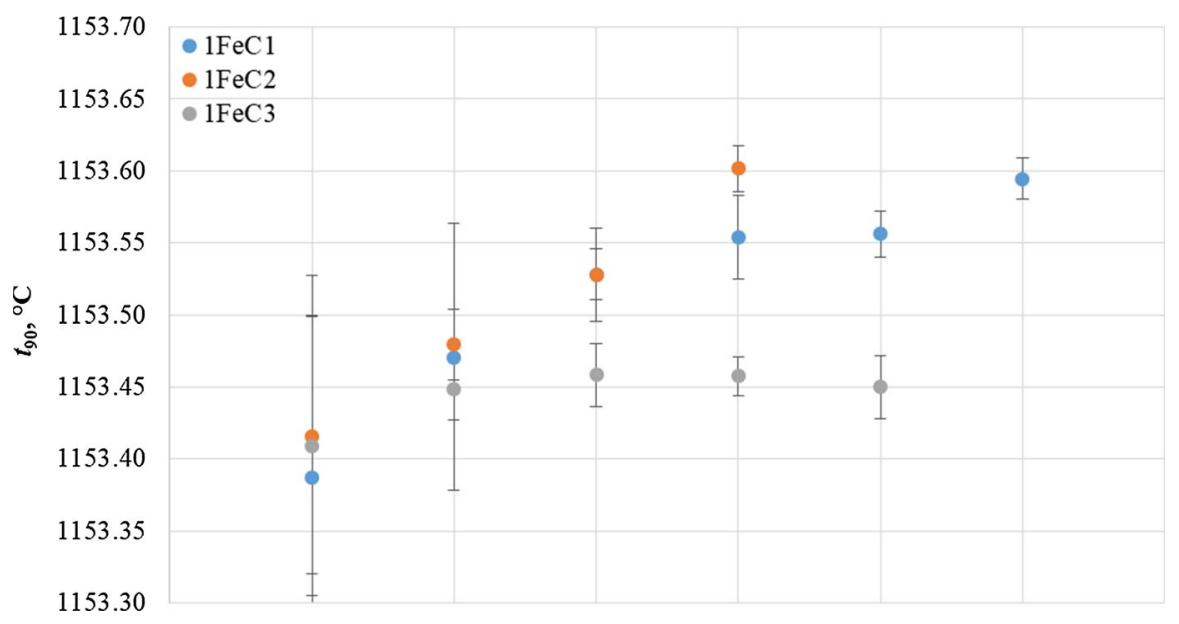

Fig. $4 t_{90}(\mathrm{POI})$ for each cell throughout the days. The graph shows the mean of all the cycles performed each day and the error bar is the repeatability of the POI each day. The temperature values have not been corrected by emissivity

\subsection{Measurement of the Cells}

Temperature measurement of the cells were made with a LP4 standard radiation thermometer. Since the LP4 is calibrated in spectral responsivity, as explained in [8], and it is referenced to a Cu fixed point blackbody, it can be used to determine $t$ and $t_{90}$ temperatures alternatively. Only the final results in Sect. 3.3 are expressed in $t$.

The cells were installed in an IR-R80 CHINO furnace. Before the installation of the cells, the furnace was baked with an Ar purge for about $1 \mathrm{~h}$, at approximately $2300 \mathrm{~K}$. The cells were installed in the furnace wrapped in graphite felt (a different wrap for each cell). The furnace window was removed during each measurement and a flow of nitrogen maintained during the measurements.

The fixed point cells were placed in the most homogeneous part of the furnace (central position). This place was determined previously using CEM HTFPs: the optimal placement was identified as the one where the melting plateaus lasted the longest and their ending was the sharpest.

\section{Results and discussion}

\subsection{Temperature Measurements}

\subsubsection{Fe-C Cells}

Three cycles were performed to the cells every day they were measured. Temperature values of the melting plateau's point of inflection, $t_{90}(\mathrm{POI})$, measured 


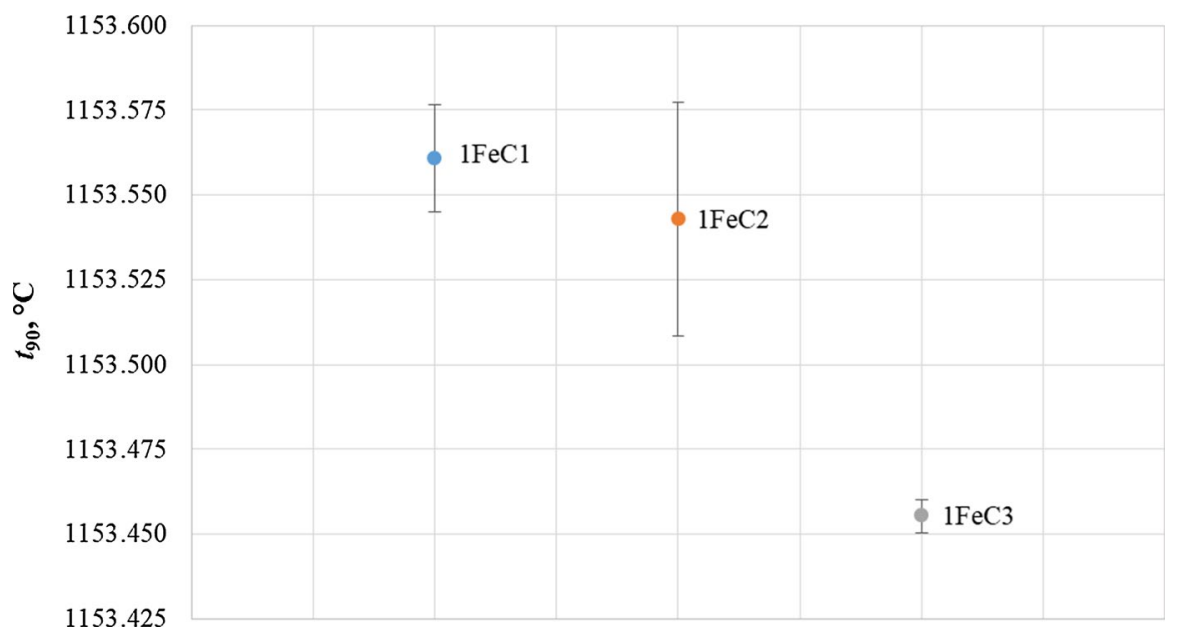

Fig. 5 POI temperature values for the three CEM Fe-C cells (after 5 days of measuring). The error bars correspond to the standard deviation for different days and cycles (1FeC3 cell shows a very good repeatability in consecutive days measurements after stabilization). The temperature values have not been corrected by emissivity

throughout the days are shown in Fig. 4. Due to the significant presence of impurities incorporated during the filling process, melts corresponding to measurements performed right after their construction presented a kink at the end of the plateau and low melting temperatures. Although these kinks could be attributed to a placement of the cell in a non-uniform position of the furnace, they were disappearing as new cycles were carried out at the same furnace's position and, simultaneously, POI melting temperatures raised until, after several days of measurements ( $\geq 3$ days), they stabilized. All temperatures indicated on figures have been calculated with the LP4 referenced to CEM's $\mathrm{Cu}$ fixed point.

NMIJ staff suggested to maintain the alloy melted for a longer period of time during the filling process in order to remove impurities more efficiently. This procedure was followed for the filling of a fourth $\mathrm{Fe}-\mathrm{C}$ cell, $1 \mathrm{Fe}-\mathrm{C} 4$, with the same materials and procedure as the used for $1 \mathrm{FeC} 1,1 \mathrm{FeC} 2$ and $\mathrm{Fe}-\mathrm{C} 3$. 1Fe-C4 was kept melted for three hours during its filling process with the result that it just required three measuring days for its melting temperature to remain stable and to remove the kink at the end of its melting plateau.

The final mean values after stabilization are plotted in Fig. 5 for illustrative purposes.

As explained in Sect. $4, t_{90}$ values for $1 \mathrm{FeC} 3$ cell are significantly lower than for $1 \mathrm{FeC} 1$ and $1 \mathrm{FeC} 2$ due to its larger aperture and consequent lower emissivity.

A complete melting/ freezing cycle with a $\pm 20{ }^{\circ} \mathrm{C}$ steps of a stable $\mathrm{Fe}-\mathrm{C}$ cell is shown in Fig. 6. 


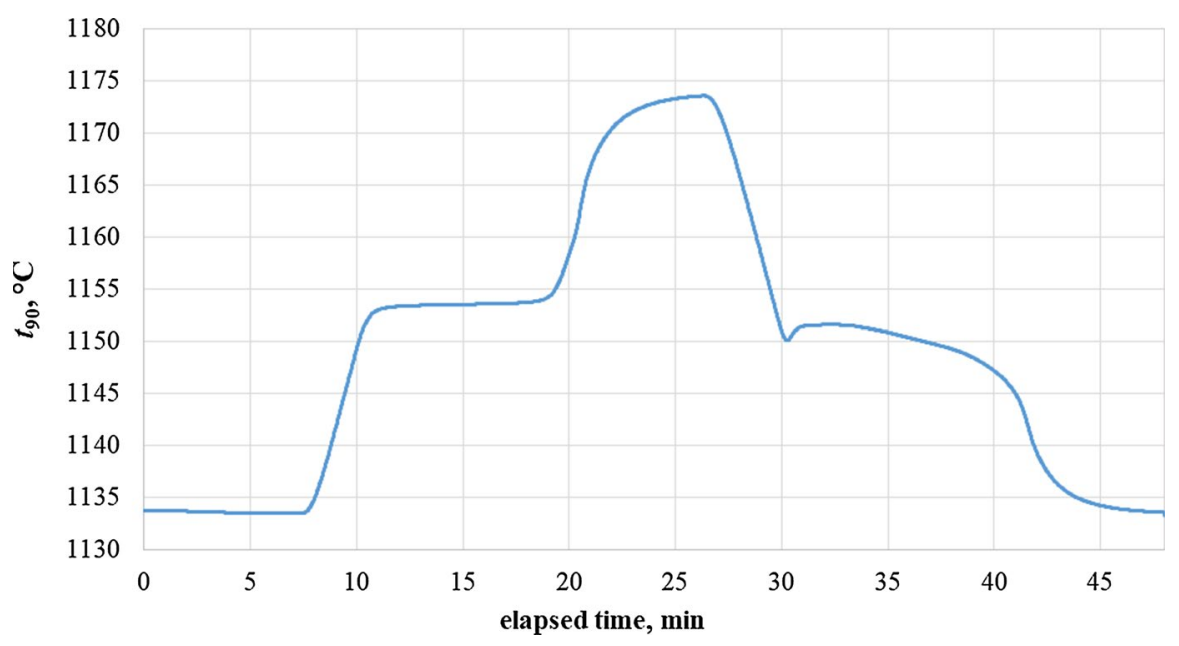

Fig. 6 Complete cycle (melting and freezing) of a $\mathrm{Fe}-\mathrm{C}$ cell for $\mathrm{a} \pm 20{ }^{\circ} \mathrm{C}$ steps (after 5 days of measuring)

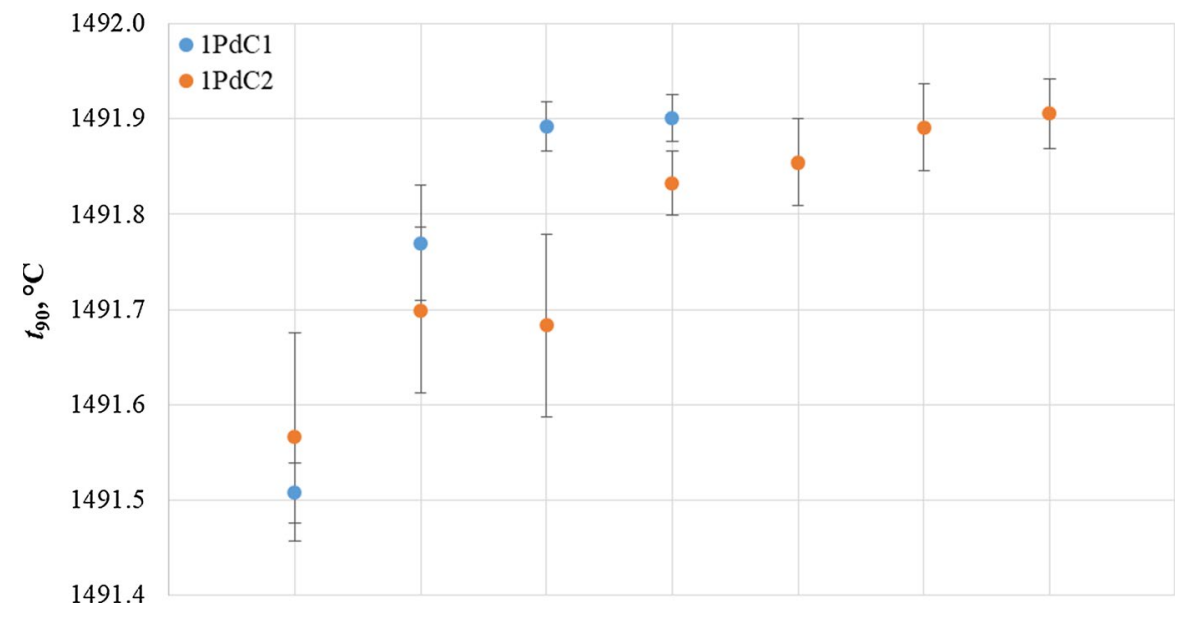

Fig. $71 \mathrm{PdC} 1$ and $1 \mathrm{PdC} 2 t_{90}(\mathrm{POIs})$ throughout the days. The graph shows the mean of all the cycles performed each day and the error bar is the repeatability of the POI each day. The temperature values have not been corrected by emissivity

\subsubsection{Pd-C Cells}

Three cycles were performed to the cells every day they were measured. Measurements were repeated throughout the days until their $t_{90}$ (POIs) stopped drifting. Temperature values of the melting plateau's point of inflection, $t_{90}(\mathrm{POI})$, measured throughout the days, are shown in Fig. 7. As it was explained in Sect. 3.1.1 for $\mathrm{Fe}-\mathrm{C}$, this initial drift is probably due to the melting time required by the 


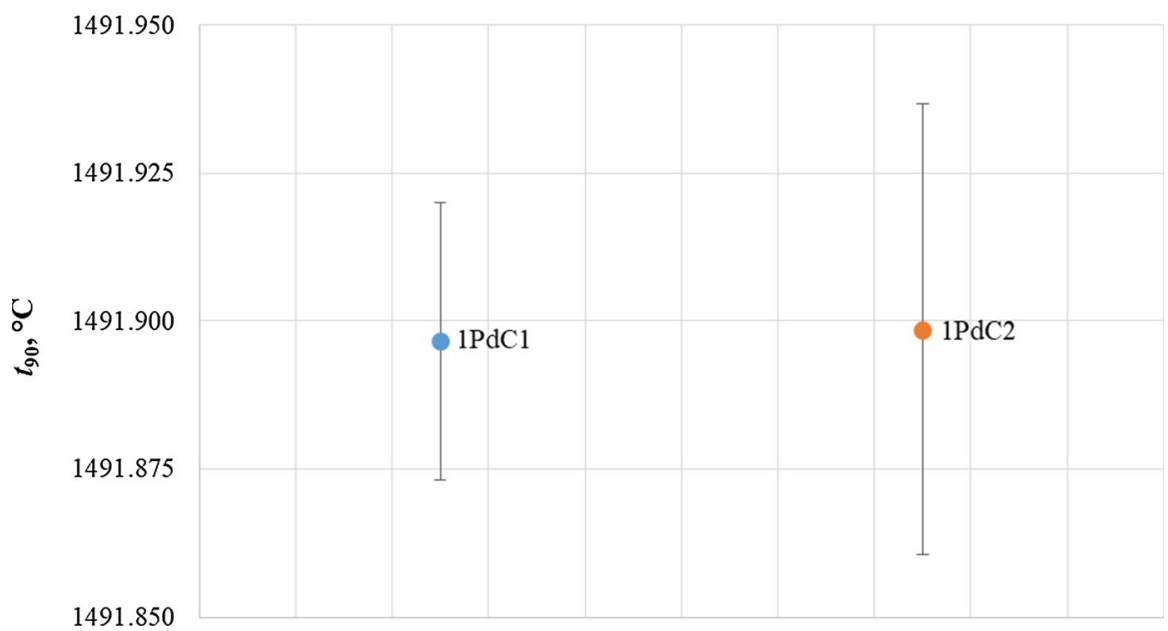

Fig. 8 POI temperatures for $1 \mathrm{PdC} 1$ and $1 \mathrm{PdC} 2$ cells (after 5 days of measuring). The error bars correspond to the standard deviation for different days and cycles. The temperature values have not been corrected by emissivity

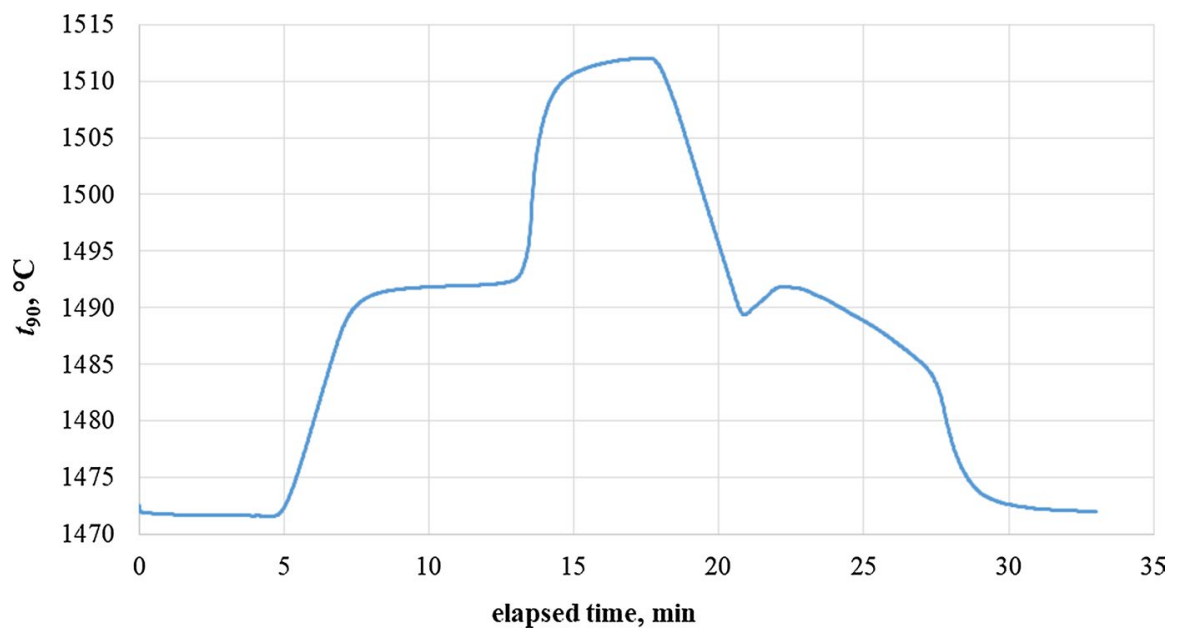

Fig. 9 Complete cycle (melting and freezing) of a Pd-C cell for a $\pm 20{ }^{\circ} \mathrm{C}$ steps (after 5 days of measuring)

alloy in order to remove impurities. All temperatures indicated on figures have been calculated with the LP4 referenced to CEM's $\mathrm{Cu}$ fixed point.

Final mean values obtained from measurements after stabilization ( $\geq 5$ days) are summarized in Fig. 8.

In Fig. 9 a complete cycle (melting and freezing) for $\mathrm{a} \pm 20^{\circ} \mathrm{C}$ steps after stabilization is shown. 


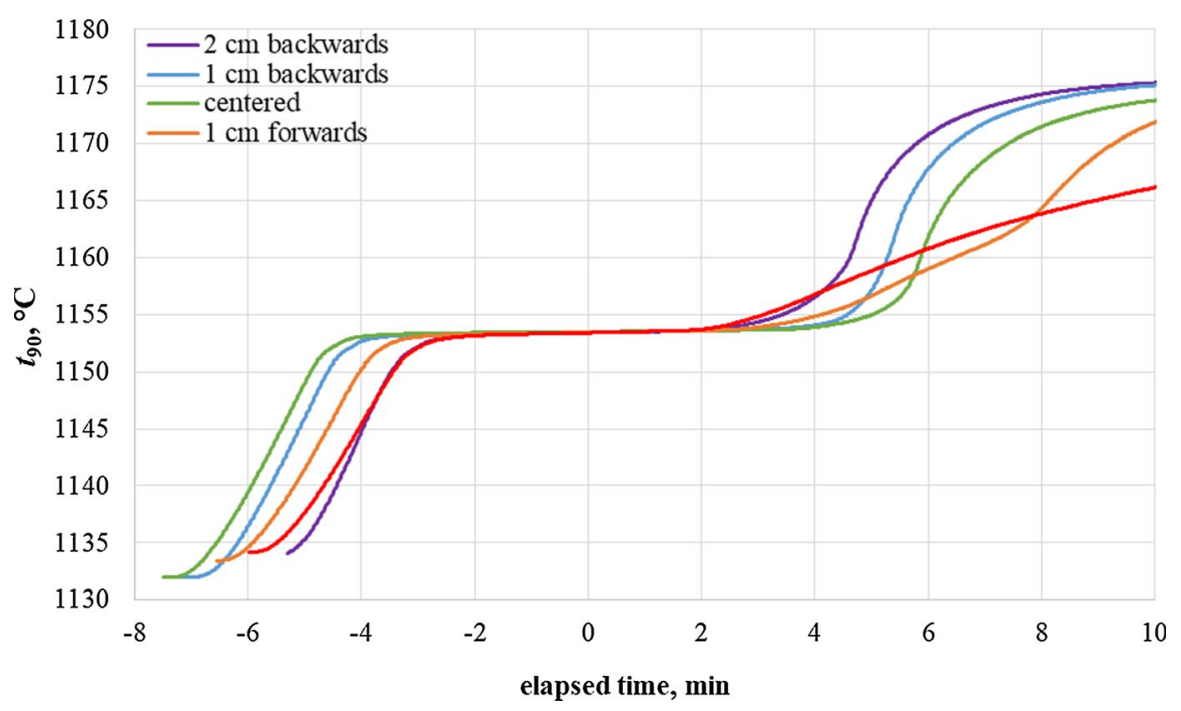

Fig. 10 CHINO furnace effect on $1 \mathrm{FeC} 2$ with $\pm 20^{\circ} \mathrm{C}$ steps

As for $\mathrm{Fe}-\mathrm{C}$ cells, it was no possible to acquire Pd powders with a better purity than $99.99 \%$. Consequently, kinks at the end of the melting plateaus corresponding to first measurement cycles of the cells were observed. It was also observed and increasing drift on the calculated POI temperature until it stabilized after several days of measurements coinciding with the disappearance of the mentioned kink. A new $\mathrm{Pd}-\mathrm{C}$ cell, $1 \mathrm{Pd}-\mathrm{C} 3$, was made with the only difference compared to the previous $\mathrm{Pd}-\mathrm{C}$ cells made during this study that its ingot was left molten for a longer period of time during the filling process. The result, as for $1 \mathrm{Fe}-\mathrm{C} 4$, was a shorter number of cycles to get the cell stable and get rid of the kink at the end of the melting plateau.

\subsection{Furnace Effect}

In this section, two influences of the furnace in the measurement of the cell temperature will be studied: the position of the cell with respect to the furnace temperature profile and the use of different furnaces (one- and three-zone).

\subsubsection{Fe-C Cell}

The furnace effect for $\mathrm{Fe}-\mathrm{C}$ cells has been measured firstly in the CHINO furnace (one heating zone) looking to the reproducibility of $1 \mathrm{FeC} 2$ cell with $\pm 30{ }^{\circ} \mathrm{C}, \pm 20{ }^{\circ} \mathrm{C}$ and $\pm 15^{\circ} \mathrm{C}$ steps when the cell is moved from the central position several cm backwards and forwards. As an example, measurements for $\pm 20{ }^{\circ} \mathrm{C}$ steps are shown below (Fig. 10, with the plateaux centered at the point of inflection). In Fig. 11, the first derivative of the curves in Fig. 10 has been plotted for a better appreciation of the behavior of the melting. 


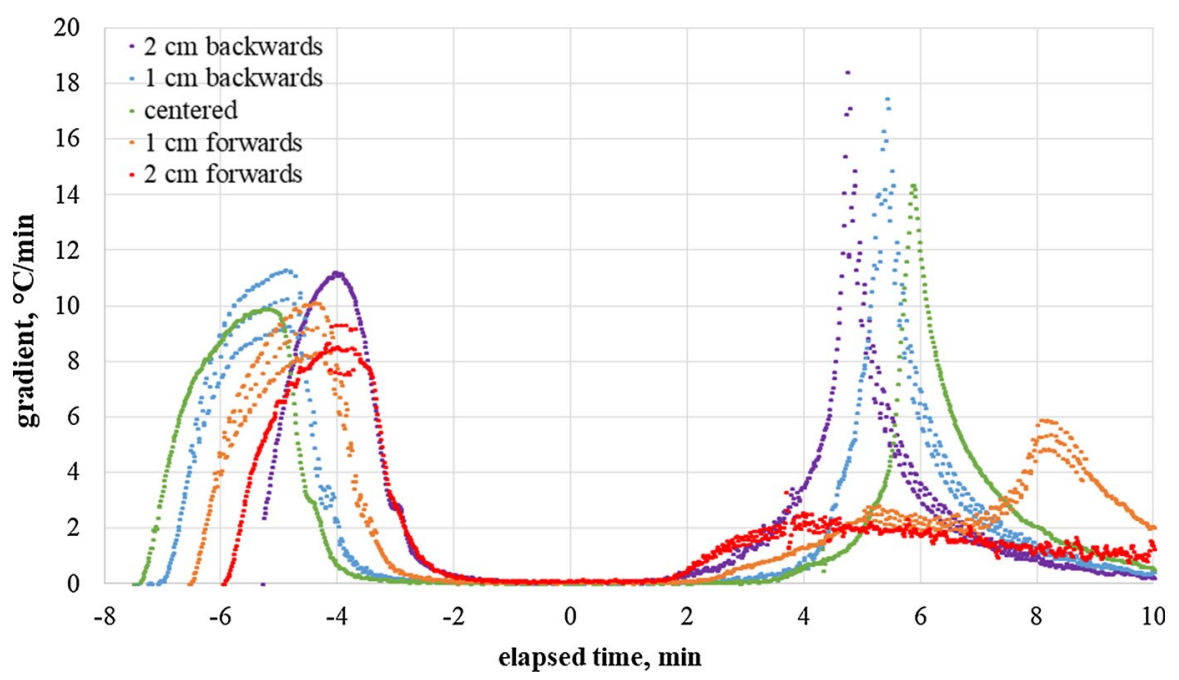

Fig. 11 First derivate of the melting curves of Fig. 10

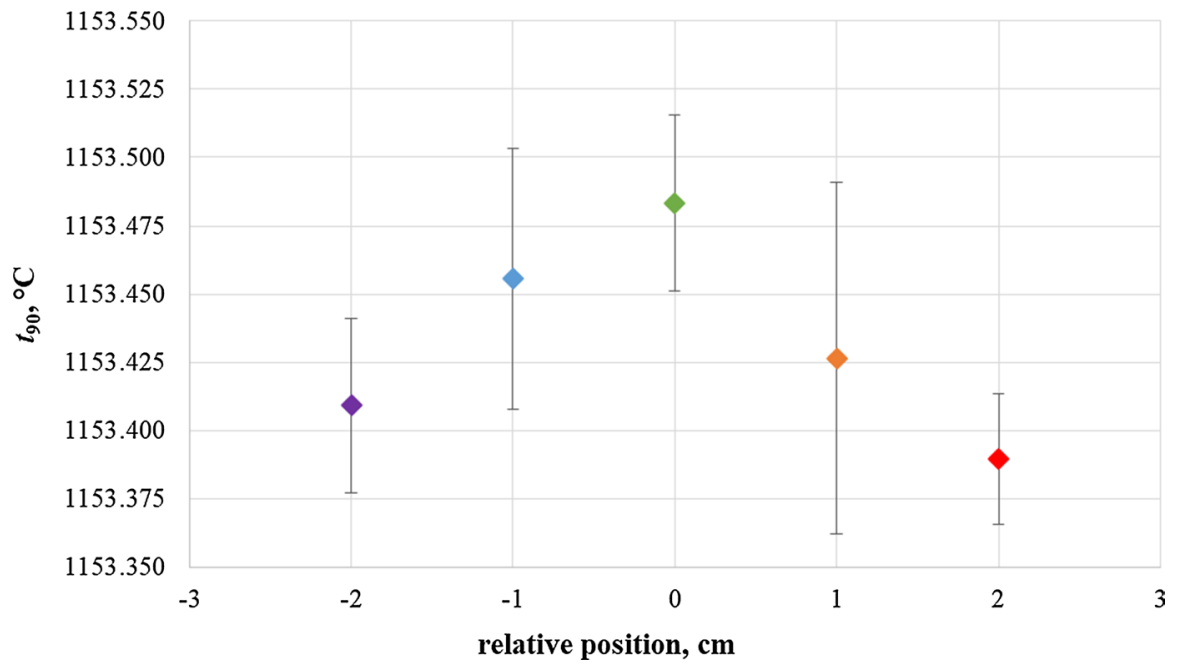

Fig. 12 Effect of the position in the $t_{90}(\mathrm{POI})$ of the $\mathrm{Fe}-\mathrm{C}$ melt $\left( \pm 20^{\circ} \mathrm{C}\right)$

The effect of the position in the POI of the melt is shown in Fig. 12. The most advantageous position is centered, with a POI total variation of approximately 0.09 ${ }^{\circ} \mathrm{C}$ in a $4 \mathrm{~cm}$ displacement.

In addition, furnace effect for the $\mathrm{Fe}-\mathrm{C}$ cells has been measured in a LENTON 3 zone furnace. In the unit used, which can reach $1200{ }^{\circ} \mathrm{C}$, heating is by a resistance wire element wound on to the ceramic work tube which is an integral part of the furnace. The end zone controllers are coupled to a center zone thermocouple enabling the center zone temperatures to be closely linked. This system provides a 


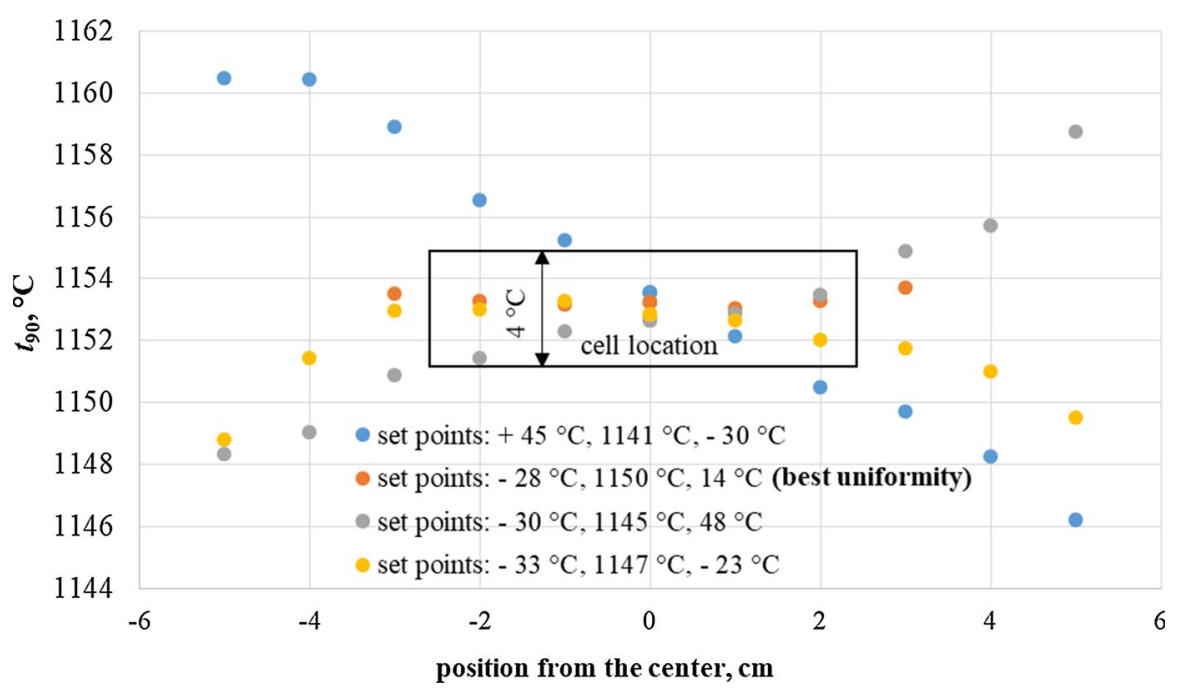

Fig. 13 Three-zone furnace temperature profile used to measure the furnace effect with Fe-C cells. The place where the cell is placed during the measurements has been pointed out with a rectangle

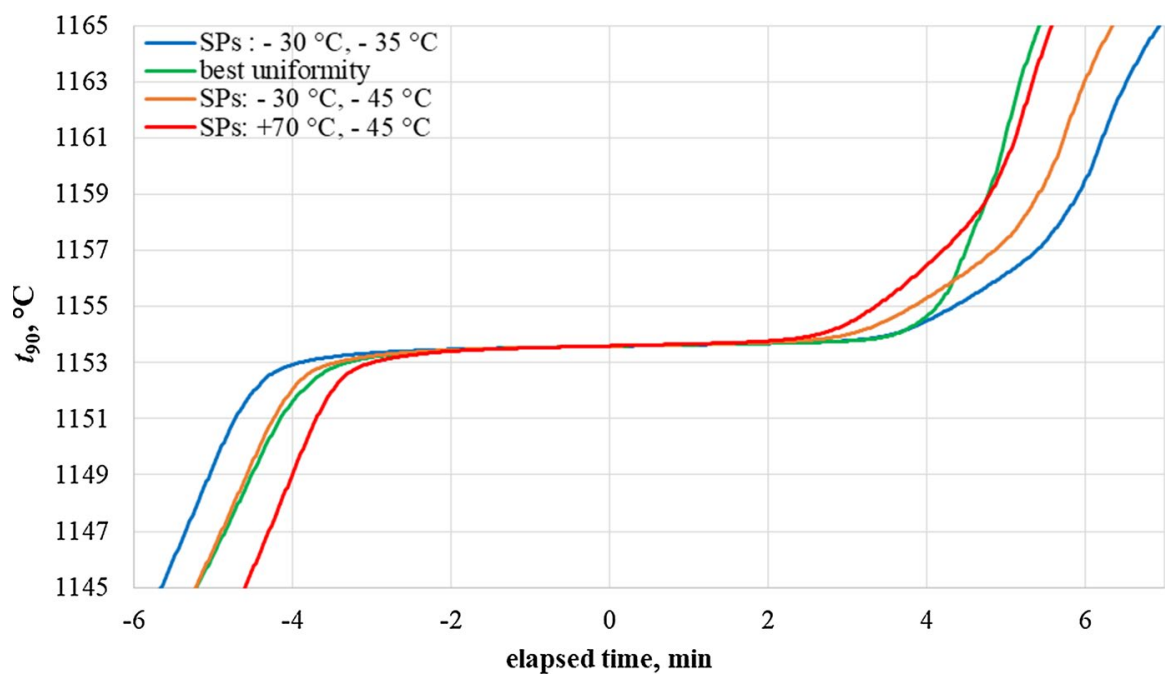

Fig. 14 LENTON furnace effect on $1 \mathrm{FeC} 3$ with $\pm 20^{\circ} \mathrm{C}$ steps. The SP's indicated are for the rear and the front zones (differential temperature)

wider temperature uniform zone than the achievable in a single zone furnace of the same length. Temperature variation within the uniform zone is typically $\pm 5^{\circ} \mathrm{C}$, with a significant proportion of the uniform zone length within $\pm 1^{\circ} \mathrm{C}$.

The temperature profiles used for the measurements are shown in Fig. 13.

As an example, measurements for $\pm 20^{\circ} \mathrm{C}$ steps are shown below for the $6 \mathrm{~mm}$ aperture cell (Fig. 14, with the plateaux centered at the point of inflection). In 


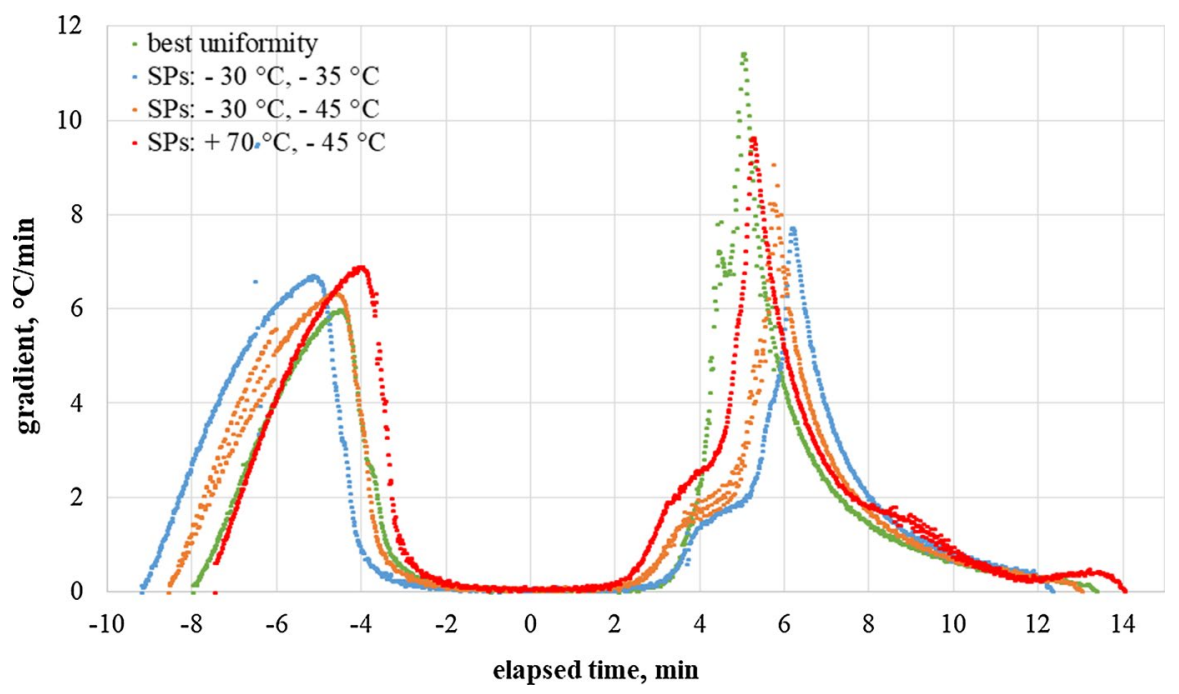

Fig. 15 First derivate of the melting curves of Fig. 14. The SP's indicated are for the rear and the front zones (differential temperature)

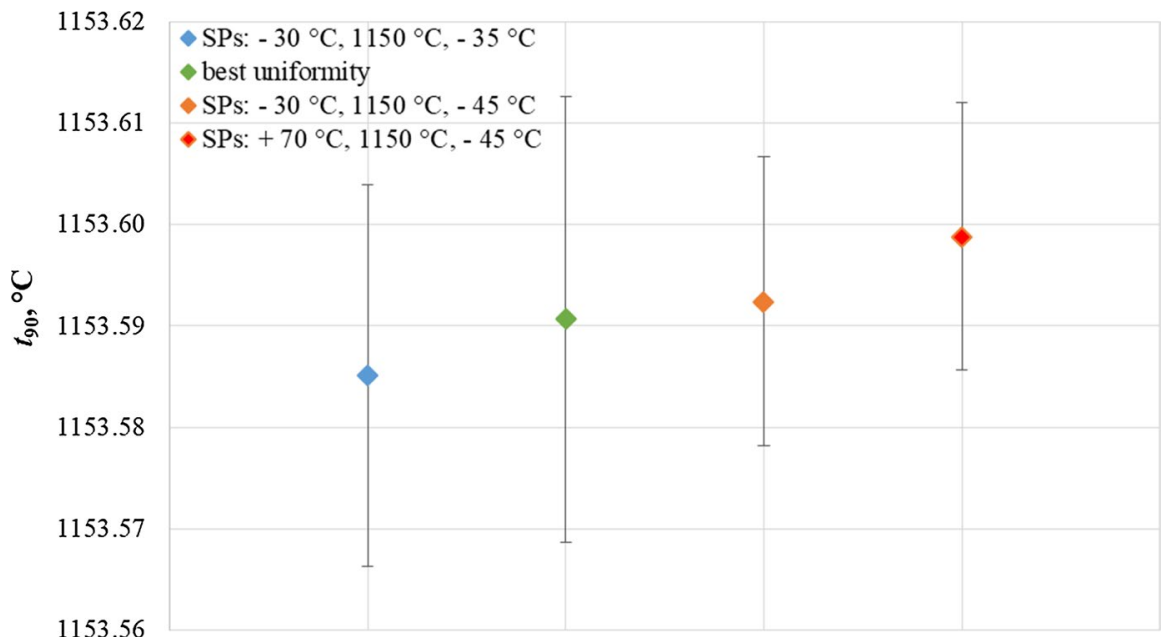

Fig. 16 Effect of the SPs change in the $t_{90}(\mathrm{POI})$ of the Fe-C $(6 \mathrm{~mm})$ melt $\left( \pm 20^{\circ} \mathrm{C}\right)$. The SP's indicated are for the rear and the front zones (differential temperature)

Fig. 15, the first derivative of the curves in Fig. 14 has been plotted for a better appreciation of the behavior of the melting.

The effect of the SPs change in the POI of the melt is shown in Fig. 16. There is nearly no significant effect compared with the results from the one-zone furnace (CHINO), see Fig. 12.

However, it has been observed that a significant difference between the $t_{90}(\mathrm{POI})$ obtained for the $6 \mathrm{~mm}$ aperture cell measured either placed the CHINO 


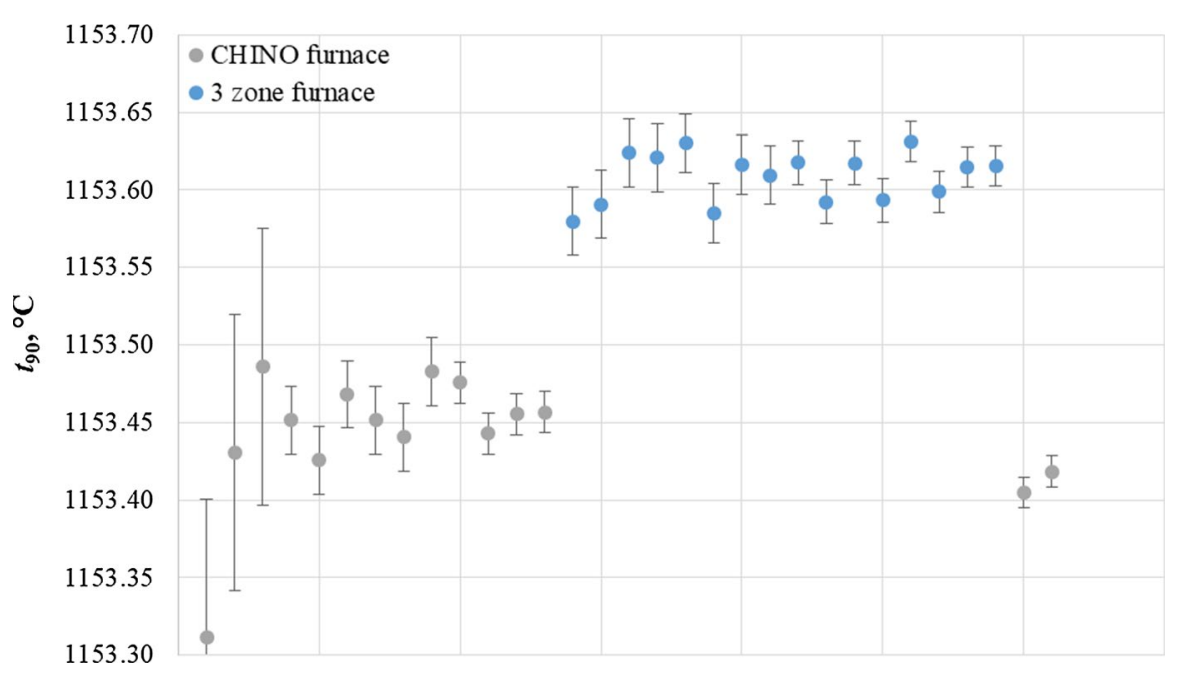

Fig. 17 Calculated $t_{90}(\mathrm{POI})$ for $6 \mathrm{~mm} \mathrm{Fe}-\mathrm{C}$ cell in CHINO and in LENTON furnaces

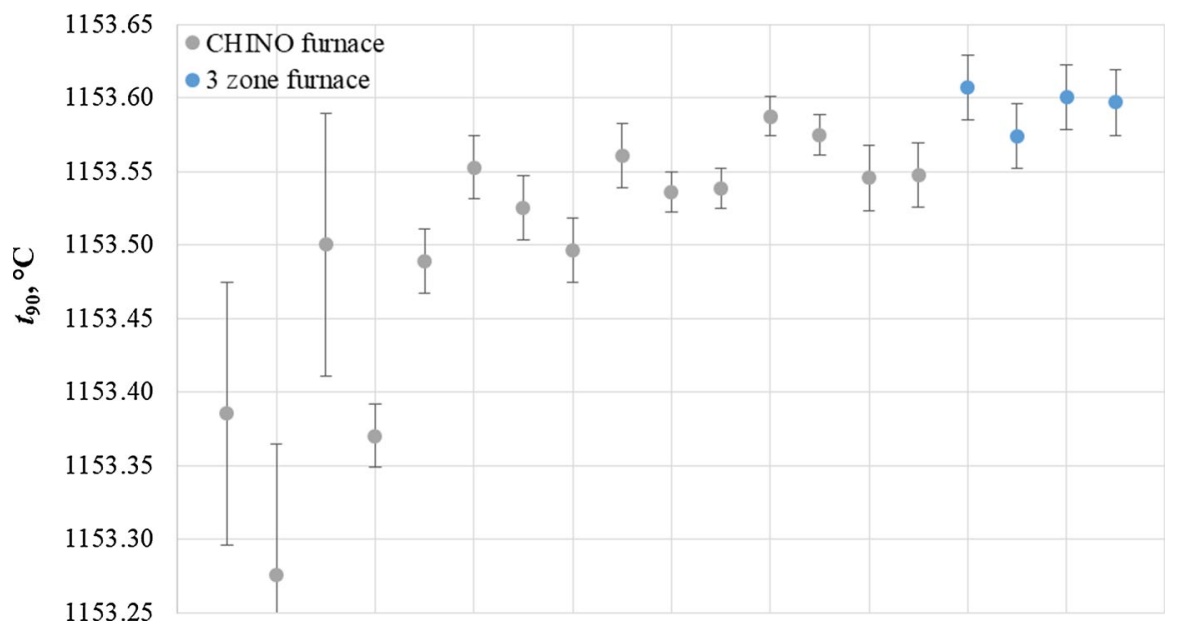

Fig. $18 t_{90}(\mathrm{POI})$ for $3 \mathrm{~mm} \mathrm{Fe-C}$ cell in CHINO and in LENTON furnaces

furnace or in the LENTON furnace. Measurements done are plotted in Fig. 17. This difference is $\cong 0.15^{\circ} \mathrm{C}$.

This effect has not been observed on $3 \mathrm{~mm}$ cells (see Fig. 18). This difference can be explained by the difference on the effective emissivity between cells with different black body diameters. However, differences in effective emissivity solely don't justify differences in melting temperature.

According to [9], different HTFP cell designs are affected by the furnace effect to a different extent so, $6 \mathrm{~mm}$ black body design of $1 \mathrm{FeC} 3$ could explain the higher values obtained, not only due to differences in effective emissivity but 


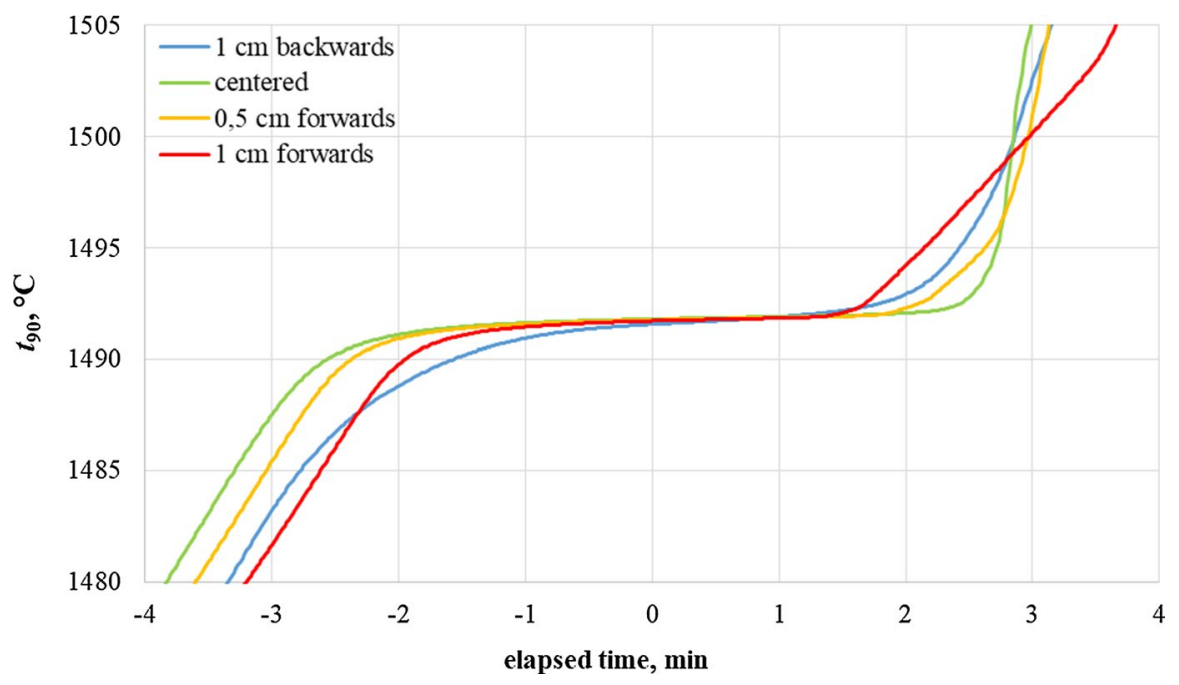

Fig. 19 CHINO furnace effect on $1 \mathrm{PdC} 1$ with $\pm 20^{\circ} \mathrm{C}$ steps

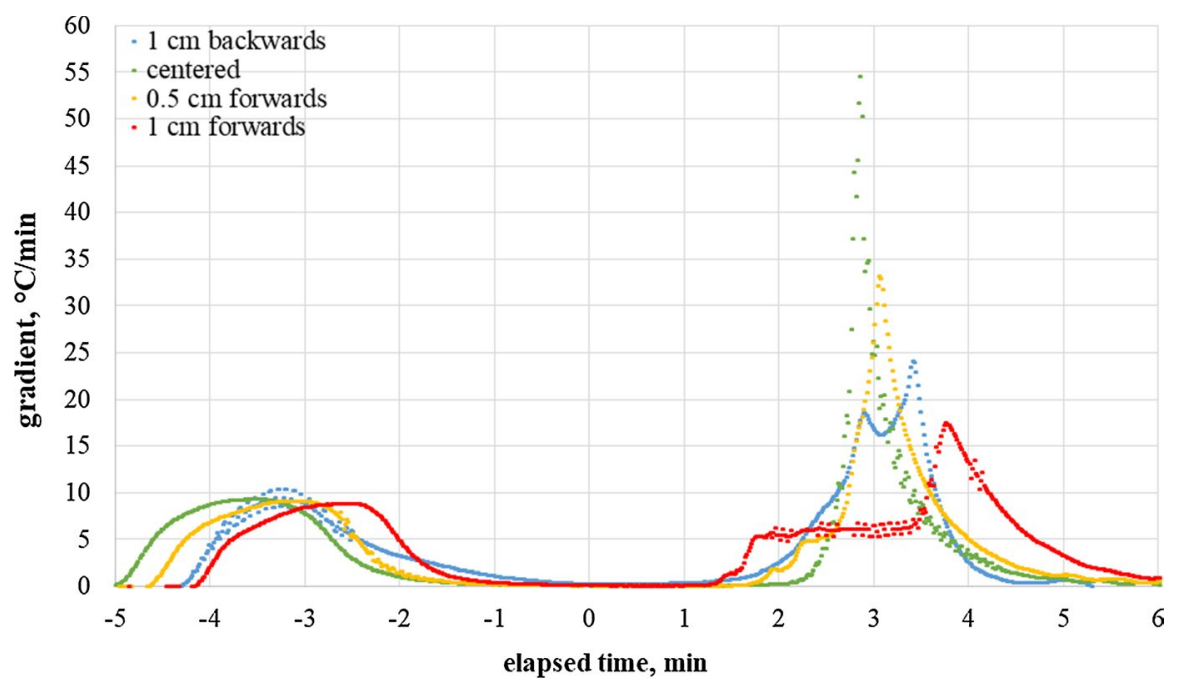

Fig. 20 First derivate of the melting curves of Fig. 19

also because furnace's temperature profile has a different effect in non-identical cell designs.

It could be of great interest for a future study to continue on the development and experimental investigation of different HTFP cell designs in order to minimize furnace effect on each eutectic fixed point of interest in order to propose a standard design for the construction of HTFP black body cells. 


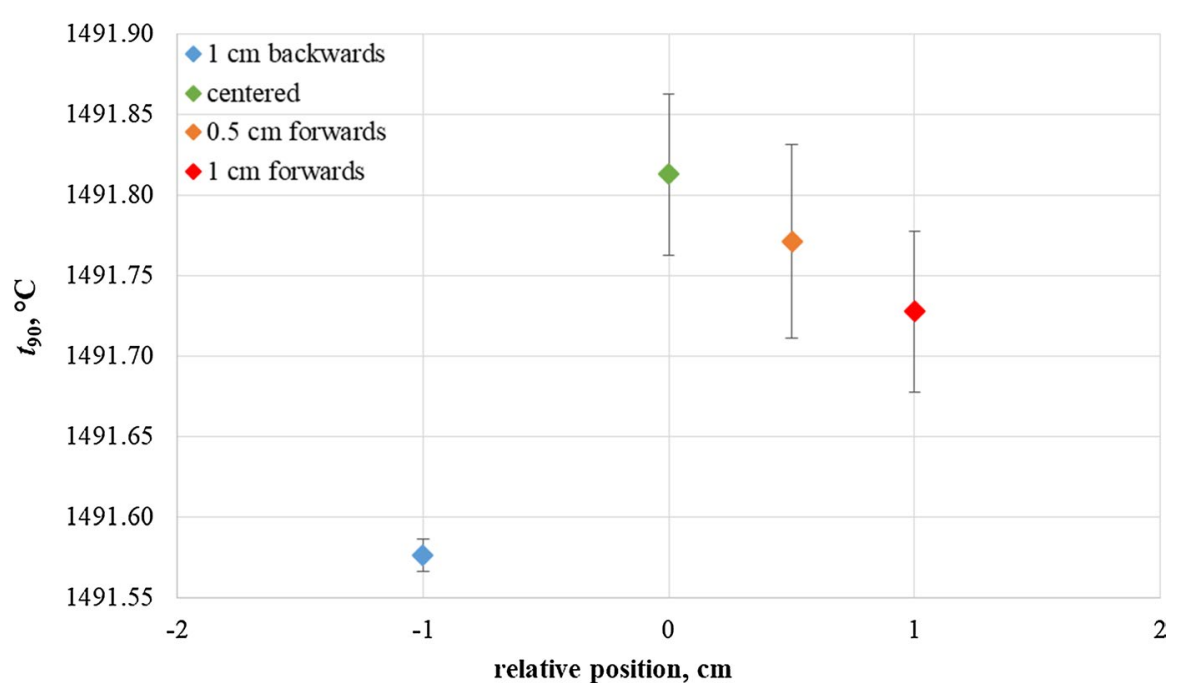

Fig. 21 Effect of the position in the $t_{90}(\mathrm{POI})$ of the Pd-C melt $\left( \pm 20^{\circ} \mathrm{C}\right)$

\subsubsection{Pd-C Cell}

The furnace effect for $\mathrm{Pd}-\mathrm{C}$ cells has been measured firstly in the CHINO furnace (one heating zone) observing the reproducibility of $1 \mathrm{PdC} 1$ cell with $\pm 30{ }^{\circ} \mathrm{C}, \pm 20^{\circ} \mathrm{C}$ and $\pm 15{ }^{\circ} \mathrm{C}$ steps when the cell is moved from the central position several cm backwards and forwards. As an example, measurements for $\pm 20{ }^{\circ} \mathrm{C}$ steps are shown below (Fig. 19, with the plateaux centered at the point of inflection). In Fig. 20, the first derivative of the curves in Fig. 19 is been plotted for a better appreciation of the behavior of the melting.

The effect of the position in the POI of the melt is shown in Fig. 21. The most advantageous position is centered, with a POI total variation of approximately 0.2 ${ }^{\circ} \mathrm{C}$ in a $2 \mathrm{~cm}$ displacement.

Furnace effect on $\mathrm{Pd}-\mathrm{C}$ cells has also been measured in a 3 zone furnace which can reach $1600{ }^{\circ} \mathrm{C}$ observing the reproducibility of $1 \mathrm{PdC} 2(3 \mathrm{~mm}$ with $\pm 30{ }^{\circ} \mathrm{C}, \pm 20{ }^{\circ} \mathrm{C}$ and $\pm 15{ }^{\circ} \mathrm{C}$ ) steps when the set points (SPs) of the lateral heater of the furnace are changed. The heating elements of this furnace are molybdenum disilicide resistances. In order to improve stability, 4 of those resistances are placed on each side zones and 6 in the central zone. In all three zones, heating elements are connected in series and are evenly distributed along the side walls. Three different type B thermocouples, one for each of the three zones, act as control sensors of this furnace. Measurements of $1 \mathrm{PdC} 2$ illustrated in this section were the very first attempt of using the mentioned 3 zone furnace for measuring fixed points of any kind and a series of issues occurred. Most important was that Ar purge displaced the cell out of its optimal position inside the furnace. Although set points of the furnace were the ones corresponding to the best uniformity profile, the two melting plateaus obtained were poorer than the in the 


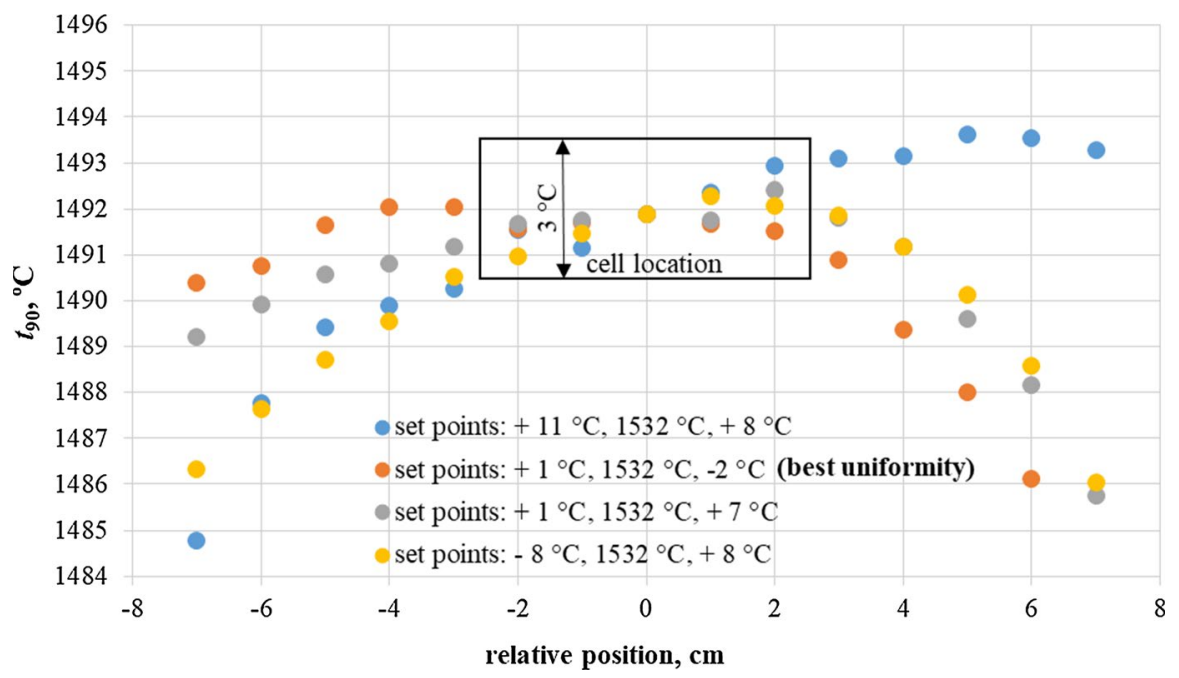

Fig. 22 Three-zone furnace temperature profile used to measure the furnace effect on $\mathrm{Pd}-\mathrm{C}$ cells. The place where the cell is placed during the measurements has been pointed out with a rectangle

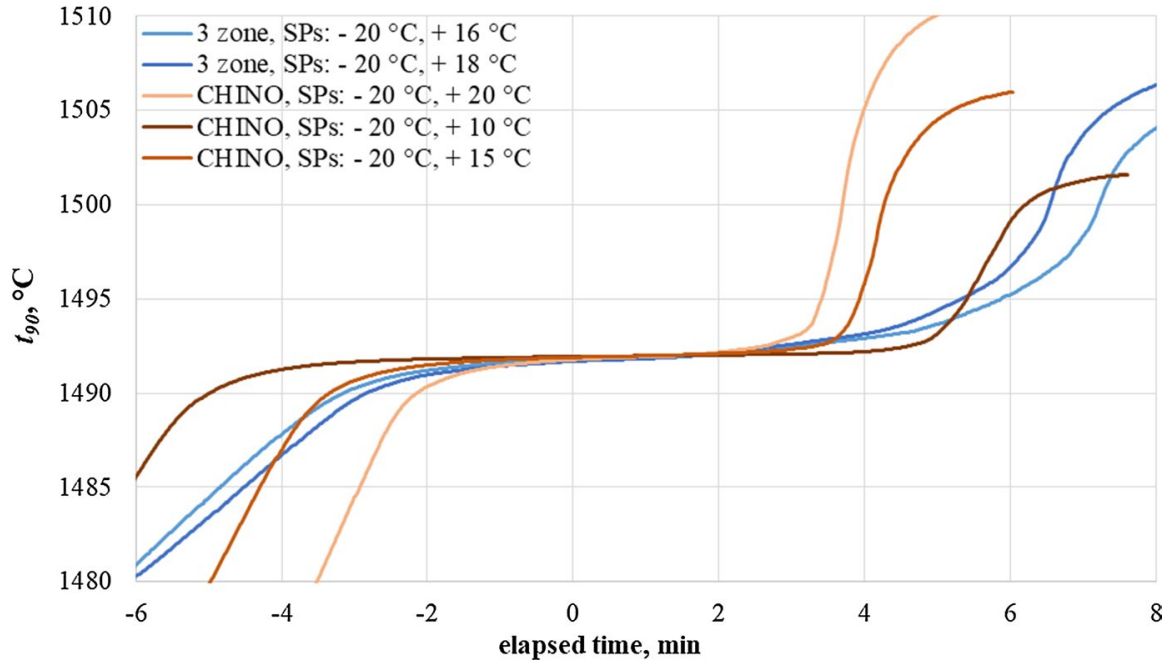

Fig. 23 CEM 1PdC2 measured in the optimal profile of two different furnaces. The 3 zone SP's indicated are for the rear and the front zones (differential temperature)

CHINO furnace, as it can be seen in Fig. 23. Then, while trying to place back the cell on the optimal position pushing it with a rod, the holding tube where the cell was placed broke. No damage was observed on the cell after an inspection once it was cooled down to room temperature. However, it was decided to stop doing 
Table 3 Final $t$ and $t_{90}$ values, corrected by the emissivity of the cells

\begin{tabular}{lllll}
\hline Cell & $t_{90},{ }^{\circ} \mathrm{C}$ & $U\left(t_{90}\right),{ }^{\circ} \mathrm{C}$ & $t,{ }^{\circ} \mathrm{C}$ & $U(t),{ }^{\circ} \mathrm{C}$ \\
\hline $1 \mathrm{FeC} 1$ & 1153.58 & 0.18 & 1153.60 & 0.23 \\
$1 \mathrm{FeC} 2$ & 1153.56 & 0.18 & 1153.58 & 0.23 \\
$1 \mathrm{FeC} 3$ & 1153.64 & 0.19 & 1153.66 & 0.24 \\
$1 \mathrm{PdC} 1$ & 1491.93 & 0.41 & 1491.95 & 0.32 \\
$1 \mathrm{PdC} 2$ & 1491.93 & 0.41 & 1491.95 & 0.32 \\
\hline
\end{tabular}

Table 4 Uncertainty budget for $t_{90}$ measurements with LP4 referenced to the Cu FP and with a wavelength of $650 \mathrm{~nm}$

\begin{tabular}{|c|c|c|c|c|c|c|}
\hline \multirow[t]{2}{*}{ Quantity } & \multirow[t]{2}{*}{ Type } & \multicolumn{2}{|c|}{ Standard uncertainty } & \multirow[t]{2}{*}{ Sens. Coef } & \multicolumn{2}{|c|}{$\begin{array}{l}\text { Contribution to } \\
\text { the combined } \\
U,{ }^{\circ} \mathrm{C}\end{array}$} \\
\hline & & $\mathrm{Fe}-\mathrm{C}$ & $\mathrm{Pd}-\mathrm{C}$ & & $\mathrm{Fe}-\mathrm{C}$ & $\mathrm{Pd}-\mathrm{C}$ \\
\hline Photocurrent meas & Normal & $2.00 \times 10^{-4}$ & $2.00 \times 10^{-4}$ & $\lambda T^{2} / c_{2}$ & 0.018 & 0.028 \\
\hline $\begin{array}{l}\text { Photocurrent meas. at } \mathrm{Cu} \\
\mathrm{PF}\end{array}$ & Normal & $2.24 \times 10^{-4}$ & $2.24 \times 10^{-4}$ & $\lambda T^{2} / c_{2}$ & 0.021 & 0.032 \\
\hline Spectral resp. & Normal & $0.085 \mathrm{~nm}$ & $0.085 \mathrm{~nm}$ & $T^{2}\left(\mathrm{~T}_{\mathrm{Cu}}^{-1}-T^{-1}\right)$ & 0.009 & 0.069 \\
\hline Linearity & Normal & $2.00 \times 10^{-4}$ & $9.00 \times 10^{-4}$ & $\lambda T^{2} / c_{2}$ & 0.022 & 0.143 \\
\hline $\mathrm{Cu}$ FP & Normal & $0.03^{\circ} \mathrm{C}$ & $0.03{ }^{\circ} \mathrm{C}$ & $T^{2} / T_{\mathrm{Cu}}^{2}$ & 0.033 & 0.051 \\
\hline Emissivity & Rectangular & $5.77 \times 10^{-4}$ & $5.77 \times 10^{-4}$ & $\lambda T^{2} / \varepsilon c_{2}$ & 0.053 & 0.081 \\
\hline \multirow[t]{3}{*}{ SSE } & Rectangular & $2.89 \times 10^{-5}$ & $2.89 \times 10^{-5}$ & $\lambda T^{2} / c_{2}$ & 0.001 & 0.004 \\
\hline & & & & $u\left(t_{90}\right)(k=1)=$ & $0.07{ }^{\circ} \mathrm{C}$ & $0.19^{\circ} \mathrm{C}$ \\
\hline & & & & $U\left(t_{90}\right)(k=2)=$ & $0.15{ }^{\circ} \mathrm{C}$ & $0.38^{\circ} \mathrm{C}$ \\
\hline
\end{tabular}

measurements on the three-zone furnace because of the high risk of cell breakage experienced on this experimental set up.

But, as in the case of $\mathrm{Fe}-\mathrm{C}$ cells, no significant effect on the point of inflection determination, compared with the results from the one-zone furnace (CHINO), has been observed.

Temperature profiles used for the measurements are shown in Fig. 22 and the results for both furnaces are shown in Fig. 23.

\section{3 $t_{90}(\mathrm{POI})$ and $t(\mathrm{POI})$ Results and Uncertainties}

Temperatures assigned to each cell are shown in Table 3. These values can be corrected by the emissivity of the cells. Emissivity of the cell has been calculated using STEEP3 ${ }^{\circledR}$ software and the values obtained are $\varepsilon=0.999772$ (for $\mathrm{Fe}-\mathrm{C}, 3 \mathrm{~mm}$ cells), $\varepsilon=0.999031$ (for Fe-C, $6 \mathrm{~mm}$ cell) and $\varepsilon=0.999807$ (for Pd-C cell).

Uncertainty budget associated to $t_{90}$ values has been calculated using [10]. ITS90 calibration of the LP4 is carried out as follows: 
Table 5 Uncertainty budget for $t$ measurements with LP4

\begin{tabular}{|c|c|c|c|c|c|}
\hline \multirow[t]{2}{*}{ Quantity } & \multirow[t]{2}{*}{ Type } & \multirow{2}{*}{$\begin{array}{l}\text { Standard uncertainty } \\
\mathrm{Fe}-\mathrm{C}\end{array}$} & \multirow[t]{2}{*}{ Sens. Coef } & \multicolumn{2}{|c|}{$\begin{array}{l}\text { Contribution to the } \\
\text { combined } U,{ }^{\circ} \mathrm{C}^{2}\end{array}$} \\
\hline & & & & $\mathrm{Fe}-\mathrm{C}$ & $\mathrm{Pd}-\mathrm{C}$ \\
\hline Monochr. Cal & Normal & $0.03 \mathrm{~nm}$ & $T\left(5 \lambda_{0} T / c_{2}-1\right) / \lambda_{0}$ & 0.045 & 0.049 \\
\hline Monochr. drift & Rectangular & $0.03 \mathrm{~nm}$ & $T\left(5 \lambda_{0} T / c_{2}-1\right) / \lambda_{0}$ & 0.043 & 0.047 \\
\hline Bandwidth & Normal & $0.07 \mathrm{~nm}$ & $T^{2} / c_{2}-12 T / \lambda_{0}+c_{2}$ & 0.013 & 0.009 \\
\hline Si detector cal & Normal & $0.038 \%$ & $-T^{2} \lambda_{0} / c_{2} / H$ & 0.034 & 0.053 \\
\hline Aperture area & Normal & $0.05 \%$ & $-T^{2} \lambda_{0} / c_{2} / H$ & 0.046 & 0.070 \\
\hline Distance & Normal & $0.01 \%$ & $-T^{2} \lambda_{0} c_{2} / H$ & 0.009 & 0.014 \\
\hline Source uniformity & Rectangular & $0.035 \%$ & $-T^{2} \lambda_{0} / c_{2} / H$ & 0.032 & 0.049 \\
\hline Source stability & Normal & $0.01 \%$ & $-T^{2} \lambda_{0} c_{2} / H$ & 0.009 & 0.014 \\
\hline Difraction & Normal & $0.01 \%$ & $-T^{2} \lambda_{0} c_{2} / H$ & 0.009 & 0.014 \\
\hline Stray light & Rectangular & $0.003 \%$ & $-T^{2} \lambda_{0} c_{2} / H$ & 0.003 & 0.004 \\
\hline OOB & Rectangular & $0.003 \%$ & $-T^{2} \lambda_{0} c_{2} / H$ & 0.003 & 0.004 \\
\hline Signal/noise & Rectangular & $0.003 \%$ & $-T^{2} \lambda_{0} c_{2} / H$ & 0.003 & 0.004 \\
\hline Si detector drift & Rectangular & $0.03 \%$ & $-T^{2} \lambda_{0} c_{2} / H$ & 0.027 & 0.041 \\
\hline Si detector linearity & Rectangular & $0.03 \%$ & $-T^{2} \lambda_{0} c_{2} / H$ & 0.027 & 0.041 \\
\hline LP4 SSE & Rectangular & $0.001 \%$ & $-T^{2} \lambda_{0} c_{2} / I$ & 0.000 & 0.000 \\
\hline LP4 Linearity & Rectangular & $0.017 \%$ & $-T^{2} \lambda_{0} c_{2} / I$ & 0.011 & 0.010 \\
\hline \multirow[t]{3}{*}{ LP4 drift } & Rectangular & $0.009{ }^{\circ} \mathrm{C}$ & $-T^{2} \lambda_{0} c_{2} / H$ & 0.009 & 0.009 \\
\hline & & & $u(t)(k=1)=$ & $0.101{ }^{\circ} \mathrm{C}$ & $0.138^{\circ} \mathrm{C}$ \\
\hline & & & $U(t)(k=2)=$ & $0.20^{\circ} \mathrm{C}$ & $0.28^{\circ} \mathrm{C}$ \\
\hline
\end{tabular}

$\lambda_{0}$ is the central wavelength, $H \cong \lambda_{0} \times C$ (with $C$ the constant at the numerator in the planckian Sakuma Hattori equation) and $I$ is the photocurrent

(1) Cu fixed point reference

(2) Measurement of the linearity with high stability tungsten lamps or variable temperature furnaces up to $2500{ }^{\circ} \mathrm{C}$

(3) Measurement of the relative spectral response using a monochromator. A high stability of the LP4 $650 \mathrm{~nm}$ interferential filter has been obtained: variation of $0.2 \mathrm{~nm}(k=2)$ in a year.

(4) Measurement of the size of source effect using an integrated sphere with the indirect method

The uncertainty budget for $t_{90}$ measurements with the LP4 is shown in Table 4.

Regarding thermodynamic temperature values, the calibration and the uncertainty calculations have been performed as explained in [11]. The uncertainty budget for $t$ measurements with LP4 is shown in Table 5 .

In order to obtain the total uncertainty associated to the fixed point temperature determination, the uncertainty associated to the LP4 $t$ or $t_{90}$ determination, calculated in Tables 4 and 5, has to be combined with the uncertainties coming 
Table 6 Final uncertainty calculation of the FP measurements $\left(t_{90}\right.$ and $\left.t\right)$

\begin{tabular}{|c|c|c|c|c|c|c|}
\hline \multirow[t]{2}{*}{ Quantity } & \multirow[t]{2}{*}{ Type } & \multicolumn{2}{|c|}{ Standard uncertainty } & \multirow[t]{2}{*}{ Sens. Coef } & \multicolumn{2}{|c|}{$\begin{array}{l}\text { Contribution to the } \\
\text { combined } U,{ }^{\circ} \mathrm{C}\end{array}$} \\
\hline & & $\mathrm{Fe}-\mathrm{C}$ & $\mathrm{Pd}-\mathrm{C}$ & & $\mathrm{Fe}-\mathrm{C}$ & $\mathrm{Pd}-\mathrm{C}$ \\
\hline$t_{90}$ (LP4) (Table 4) & Normal & $0.07{ }^{\circ} \mathrm{C}$ & $0.19^{\circ} \mathrm{C}$ & 1 & 0.070 & 0.190 \\
\hline Structure effect & Normal & $0.014{ }^{\circ} \mathrm{C}$ & $\mathrm{n} / \mathrm{a}$ & 1 & 0.014 & 0.000 \\
\hline POI determination & Normal & $0.03{ }^{\circ} \mathrm{C}$ & $0.046^{\circ} \mathrm{C}$ & 1 & 0.030 & 0.046 \\
\hline Stability & Normal & $0.034{ }^{\circ} \mathrm{C}$ & $0.007{ }^{\circ} \mathrm{C}$ & 1 & 0.034 & 0.007 \\
\hline Furnace effect ${ }^{\mathrm{a}}$ & Rectangular & $0.09^{\circ} \mathrm{C}$ & $0.20^{\circ} \mathrm{C}$ & $\begin{array}{l}1 \\
u\left(t_{90}\right)(k=1)= \\
U\left(t_{90}\right)(k=2)=\end{array}$ & $\begin{array}{l}0.026 \\
0.088^{\circ} \mathrm{C} \\
0.18{ }^{\circ} \mathrm{C}\end{array}$ & $\begin{array}{l}0.058 \\
0.205^{\circ} \mathrm{C} \\
0.41^{\circ} \mathrm{C}\end{array}$ \\
\hline$t$ (LP4) (Table 5) & Normal & $0.101{ }^{\circ} \mathrm{C}$ & $0.138^{\circ} \mathrm{C}$ & 1 & 0.101 & 0.138 \\
\hline Structure effect & Normal & $0.014^{\circ} \mathrm{C}$ & $\mathrm{n} / \mathrm{a}$ & 1 & 0.014 & 0.000 \\
\hline POI determination & Normal & $0.03{ }^{\circ} \mathrm{C}$ & $0.046^{\circ} \mathrm{C}$ & 1 & 0.030 & 0.046 \\
\hline Stability & Normal & $0.034{ }^{\circ} \mathrm{C}$ & $0.007{ }^{\circ} \mathrm{C}$ & 1 & 0.034 & 0.007 \\
\hline Furnace effect ${ }^{\mathrm{a}}$ & Rectangular & $0.09^{\circ} \mathrm{C}$ & $0.20^{\circ} \mathrm{C}$ & $\begin{array}{l}1 \\
u(t)(k=1)= \\
U(t)(k=2)=\end{array}$ & $\begin{array}{l}0.026 \\
0.115^{\circ} \mathrm{C} \\
0.23{ }^{\circ} \mathrm{C}\end{array}$ & $\begin{array}{l}0.058 \\
0.158{ }^{\circ} \mathrm{C} \\
0.32{ }^{\circ} \mathrm{C}\end{array}$ \\
\hline
\end{tabular}

For the "Structure effect" values in [12] have been used. For "POI determination", it has been used the maximum standard deviation for the cycles in the same day and for the "Stability", the maximum standard deviation in different days, both cases after cell stabilization. For the "Furnace effect" values in Sect. 4 has been used.

${ }^{\mathrm{a}}$ In case of $6 \mathrm{~mm} \mathrm{Fe}-\mathrm{C}$ cell, a value of 0.15 is used instead of 0.09 , to get the uncertainty shown in Table 5 for this cell

from the fixed point itself [12]. The final uncertainty budgets for the FPs $t$ and $t_{90}$ determination are shown in Table 6.

\section{Conclusions}

Several cells of $\mathrm{Fe}-\mathrm{C}$ and $\mathrm{Pd}-\mathrm{C}$ have been constructed at CEM. Although not ideal, chemical analysis of the ingots reported a valid purity for the transition temperature determination of these eutectic fixed points. After a few initial measurements, that served to accommodate and purify cell's ingots, their melting temperatures increased and got stable. No damage has been appreciated on the cells after a substantial number of measurement cycles.

The $t_{90}$ and $t$ values of the cells have been assigned using CEM's standard radiation thermometer.

Measurements of the furnace effect have been performed in different furnaces available at CEM (one-zone, three-zone). In case of $3 \mathrm{~mm}$ aperture cells, this effect is lower or in the order of the measuring uncertainty and it is only significant in the one-zone furnace: $0.09{ }^{\circ} \mathrm{C}$ for $\mathrm{Fe}-\mathrm{C}$ and $0.15^{\circ} \mathrm{C}$ for $\mathrm{Pd}-\mathrm{C}$, as maximum values.

In the case of $\mathrm{Fe}-\mathrm{C} 6 \mathrm{~mm}$ cell, the difference between the temperatures measured in the three-zone and one-zone furnace is large, $0.15{ }^{\circ} \mathrm{C}$, compared with the $3 \mathrm{~mm}$ 
cells, $0.03{ }^{\circ} \mathrm{C}$, so the final uncertainty assigned to this cell will need to be increased during the dissemination activities.

Acknowledgements The project 18SIB02 Real-K "Realizing the redefined kelvin" has received funding from the EMPIR programme co-financed by the Participating States and from the European Union's Horizon 2020 research and innovation programme.

Open Access This article is licensed under a Creative Commons Attribution 4.0 International License, which permits use, sharing, adaptation, distribution and reproduction in any medium or format, as long as you give appropriate credit to the original author(s) and the source, provide a link to the Creative Commons licence, and indicate if changes were made. The images or other third party material in this article are included in the article's Creative Commons licence, unless indicated otherwise in a credit line to the material. If material is not included in the article's Creative Commons licence and your intended use is not permitted by statutory regulation or exceeds the permitted use, you will need to obtain permission directly from the copyright holder. To view a copy of this licence, visit http://creativecommons.org/licen ses/by/4.0/.

\section{References}

1. CCT MeP-K CCT, Mise en pratique for the definition of the kelvin in the SI. Consultative Committee for Thermometry SI Brochure, 9th edn-Appendix 2 (2019). https://www.bipm.org

2. Realising the redefined kelvin. 18SIB02-Real-K. https://www.researchgate.net/project/Realisingthe-redefined-kelvin-18SIB02-Real-K

3. J.M. Mantilla, D.J. Woods, R. Emms, M.J. Martín, A.D.W. Todd, D. del Campo, Construction and comparison of high temperature fixed points at NRC and CEM, in Journal of Physics: Conference Series. Tempmeko'19 Conference Proceedings, Chengdu, China (2019).

4. F. Bourson, S. Briaudeau, B. Rougie, M. Sadli. Tempbeijing. Acta Metrol. Sin. 29 4A, Beijing, China (2008). https://www.researchgate.net/profile/Mohamed-Sadli/publication/259639728_Devel opments_around_the_Co-C_point_at_LNEINMCnam/links/0c96052d00a8cd5f17000000/Devel opments-around-the-Co-C-point-at-LNE-INM-Cnam.pdf

5. M. Sadli, O. Pehlivan, F. Bourson, A. Diril, K. Ozcan, Collaboration between UME and LNE-INM on $\mathrm{Co}-\mathrm{C}$ eutectic fixed-point construction and characterization. Int. J. Thermophys. 30, 36-46 (2009)

6. F. Edler, Y.G. Kim, G. Machin, J. Pearce, D.R. White, "Guide on Secondary Thermometry. Specialized Fixed Points above $0{ }^{\circ} \mathrm{C}$ ". https://www.bipm.org/documents/20126/41773843/Specialized-FPsabove-0C.pdf/10265617-c79f-0ea5-8da9-8d359e21c6be

7. P. Bloembergen, Y. Yamada, N. Sasajima, Y. Wang, T. Wang, The effect of the eutectic structure and the residual effect of impurities on the uncertainty in the eutectic temperatures of $\mathrm{Fe}-\mathrm{C}$ and Co-C. Metrologia 44, 279-293 (2007)

8. M.J. Martin, J.M. Mantilla, D. del Campo, M.L. Herranz, A. Pons, J. Campos, Performance of different light sources for the absolute calibration of radiation thermometers. Int. J. Thermophys. 38, 138 (2017)

9. Y. Yamada, Investigation on the cause of the furnace effect of high-temperature fixed points. Meas. Sci. Technol. 32, 015009 (2020)

10. J. Fischer, M. Battuello, M. Sadli, M. Ballico, N. Park, P. Saunders, Y. Zundong, B.C. Johnson, E. Van, H. Nmi, W. Li, F. Sakuma, G. Machin, N. Fox, S. Ugur, M. Matveyev, CCT-WG5 on radiation thermometry "Uncertainty budgets for realization of scales by radiation thermometry", CCT03-03, p. 1-25. https://www.bipm.org/cc/CCT/Allowed/22/CCT03-03.pdf

11. P. Saunders, E. Woolliams, H. Yoon, A. Todd, M. Sadli, E. van der Ham, K. Anhalt, L. Werner, D. R. Taubert, S. Briaudeau, B. Khlevnoy, Uncertainty estimation in primary radiometric temperature measurement. CC-WG-NCTh document, May 2018

12. Document CCT-WG-NCTh/18-06 "HTFP Uncertainties" A. Todd et al.

Publisher's Note Springer Nature remains neutral with regard to jurisdictional claims in published maps and institutional affiliations. 